\title{
The External Factors That Influence the Image of Disney Movies Characters
}

\author{
Jiru Huang \\ GuangDong Country Garden school, Foshan, GuangDong, China. \\ 1466094598@qq.com
}

\begin{abstract}
Disney is a successful movie producer which produce many popular series. There are researches that discuss how the concept change affects the characters designed by Disney, for example how the change of gender role change Disney princess characteristic. However, these papers tend to focus on limited aspect, only on social consensus or culture background of specific movies. In this paper, the author discusses several external factors culture, social consensus, audience feedback illustrates in multiple Disney movie. The design of movie characters does not only serve the plot, especially when movie becomes a mean of cultural export. Looking back the example of Disney movie provide an aspect for producer to view how to converge culture and another external factor in the movie and made the movie being accept by the majority.
\end{abstract}

Keywords: Disney, Movie, cultural research, social consensus, historical background

\section{INTRODUCTION}

Many reseachers analysed the culture background of one specific Disney movie, or one aspect on Disney series. For example, some reseachers disscussed the change in body image, gender role and illustrate the romantic role in Disney princess, but there are no research that include multiple aspects, from historical background to social consensus and analyses multiple Disney movie to deduce how these external factor works together, and how these factor influence the feedback of the movies. In this paper, the author uses textual studies, focus on the movie content and other research analyses the culture background behind the movie content. This paper provide an overview of the external factor that influence the way Disney creating character, and cater the consensus is a factor of successful movie, this research may provide an aspect for creator to reference how the successful producer consider external factor when creating character and how these mindset can be use when creating their own work.

\section{THE INFLUENCE OF HISTORICAL BACKGROUND}

Historical background plays a role in Disney when creating character, each character creation not only fits the plot, but also considers the specific historical background in the production. The first example is the Star Wars that produce in the background of the Cold War, when both facing the threat of Soviet Union and the economic recession, Star War illustrates character like Han Solo, a man that can joke with his partner when facing crisis. This kind of character really motivates audience and provides a sense of power [9]. When the situation changes, the theme in the movie would also be changed. The theme in Star Wars Prequel Trilogy shifts from "individual heroism" to the "collapse of individual heroism"[9]. The storyline of Anakin Skywalker is an example, he is overwhelmed with hatred and fall toward the dark side, eventually become a villain. The character is an epitome of the United State after winning the Cold War. After United State gain the international right of speech, there are several movements that only consider the county's own interest. The producers use an extreme character that put one's own thought on the first place to imply a kind of reflection. The historical background does not only appear in the movie that contain lot of political element like Star Wars even the design of Disney princess reflects a certain of historical value when they design characters, these innocent girls figure are trying to made people forget the harsh crisis like the economic crisis[19]For example, Cinderella and Snow White are extremely innocent and kind even when facing the 
villain like the cruel stepmother and stepsisters, and they eventually marry the handsome prince is a kind of implication that everything would pass and end happily.

\section{THE INFLUENCE OF CULTURE}

Disney, as an American movie franchise, illustrates American culture in their movie, and these culture factors influence how the character is shaped in the movie. "The American Dream" is an example of culture factor in Disney movie, many movies express the view that anyone can achieve the goal by hardworking and against prejudice. Zootopia is a very typical example [12] The movie mocks the prejudice by setting contrast in many characters' feature. [12] For example, the main character Judy is a rabbit, but she becomes a police like the other huge predators do. Fox often be interpreted as a cunning character, but Nick, a fox character in Zootopia helps Judy in the movie. A sheep seems to be an innocent and kind animal, but the sheep in Zootopia is the actual villain. Such kind of character set up reflect the inclusiveness of American culture [22] Apart from inclusiveness, everyone can achieve their goal by hardworking is also a theme being expressed in the Disney movie. A Disney- Pixar movie Ratatouille is an example expressing this theme. The main character in Ratatouille is a rat name Remy who wants to become a cook, but as a rat, he could never be in the kitchen. The other main character Linguini is a janitor in the kitchen, he wants to be a cook, but he is bad in cooking. By making the two characters who seems impossible to become a cook to become successful in cooking echoing a line in the film "Everyone can cook", it also implies a value that everyone can achieve their dream with hardworking and courage. [3]. Another aspect of American culture, individualistic heroism is also illustrates in Disney- Pixar movies, there are plots that the main character breaks the taboo and save one's community or friends thorough adventure. For example, The Disney- Pixar movies A Bug's life illustrates an ant name Phyllis who try to design machines to make gathering food more effective, but his machine creates more accidents than progress. Unlike other ants that focus on gathering enough food to give to grasshoppers in order to prevent being robbed, Phyllis leave the tribe to find help to defeat the grasshoppers. "Leaving the tribe" and "Breaking the taboos" are two common motif in American movie, and blend these motif on the movie main character illustrate the individualistic heroism. Apart from American culture, Disney also contain stories from other culture, and the story from different background would also influence the feature of character. Mulan is a significant example of Disney referencing other culture. Mulan's original story comes from the Chinese folktale in the Northern Dynasties [15] so when Disney design the character, her motivation is to marry a decent man and brings honor to her family, which is the typical mindset for women in ancient China[14].

\section{THE INFLUENCE OF SOCIETY CONSENSUS}

Another factor that influence the change in Disney character is the society consensus, especially the one on gender role, which can be seen in Disney Princess. At first, most of the Disney princess movies like Snow White and the Seven Dwarf and Cinderella emphasize kindness and innocent as the feature of princess[21]. they are submission characters who tend to be saved by others rather than solve the crisis my themselves. For example, In Snow White and the Seven Dwarf. Snow White first been saved by the dwarfs then been saved when the prince kissed her. The similar plot happens in Sleeping Beauty. In 1937, when the Snow White and the Seven Dwarf produced, people tend to believe woman should stay at home doing chores while man work outside [3]. The movie catered this kind of mindset by showing scene that Snow White singing and doing chores for the dwarf while the dwarf working in mines.[5] These kinds of plots emphasize the kindness of character. The similar role shaping is used in Cinderella which the main character working hard, doing all kinds of housework so she can be loved by her mean stepmother. Another aspect of Disney Princess movies cater the consensus of women is that the villains are mostly powerful female [10], like the queen in Snow White and the Seven Dwarf and the stepmother in Cinderella. The males often play the savoir and always be the positive character. In the second phase, the princess character become more powerful while reserve some feminine traits[2]. This kind of change may be due to the feminist movement that made the majority to rethink the role that women plays in the society[10]. When looking to Disney movie, it illustrates in a form that the princess is not being a beautiful girl that obey their faith, but to make their own decision, showing independent and masculine traits. [10] For example, Ariel makes a decision to leave the sea and go on the land to find the man she saves, which is the decision against what her father wants, showing the rebelliousness of the character[20]. Another trait is that these female characters goal change from "Marry the prince" to "Doing what they want". A typical example is the main character in Princess and the Frog who wants to open her own restaurant. In some movies in the Disney second era, the main character is as strong as male. Mulan may be a typical example showing the power of female. In the movie, Mulan replaces her father to join in the army, and save her male partner with her wisdom. [20] However, the princesses in the Disney second phrase does not totally get rid of stereotype. [20] Marrying, returning home and romantic element still plays an important role in these movies. [5] Ariel marry the prince, even the most powerful princess 
Mulan shows her female character and end up with marrying in the end of the movie. After 1980, the theme of feminist movement shift from competing with males to cooperate with the males while admit the difference between different gender. Overcome the self-abasement become the theme. This change also affect how Disney shape their princess characters. The most significant change is that the character breaks the gender role further than the second era, showing even more independent and power. [17] Merida from Brave is an example, like Mulan, she is powerful and has masculine power. She used weapons and ride horse in the movie, and she was thrilled when she received a bow as present. [18] The most significant difference between her and Mulan is that Mulan join in the army to protect her father, her motivation is still base on family. However, Merida refuse to marry, the motivation is based on her own wish. Mulan in the starts of the movie has doubt herself being unable to marry a good husband and bring honor to the family, Merida, on the contrary rarely questioned herself. [1][18] Another difference in the third era movie is the movies challenged the old rules that the movie end with princess finds a romantic suitor. Frozen is a typical example, the movie goes further than mentioning finding a romantic suitor is not the only way toward the happy end by mocking the traditional plot of prince and princess fall in love in the first sight. [11][16]. In the movie, Hans eventually being the villain who marries Anna in order to be the king. It is the first time in Disney movie that illustrating prince as a villain, unlike the prince character in first era that being flawless.

\section{THE POSITIVE FEEDBACK AND LIMITATION IN PRODUCTION}

Movie being an art form that require large amount of investment, the feedback of audience plays an important role in production, especially for the commercial movie producer Disney. By cater the change on social consensus and express the mainstream theme, Disney receive positive feedback both on commercial and reputation. For example, the movie Brave gain a relative well gross $(\$ 237,283,207)$ that cover the budget $(\$ 185,000,000)$ [7] which indicate the image of a masculine princess without romantic factor is actually accept by the audience. A year after Brave released, Frozen being the first movie that break the traditional rules of prince being the savior shows great success in the box office, gaining $\$ 400,953,009$ in the domestic box office, and the movie even be the rank number 2 when release in Japan [8]. Apart from the positive feedback in box office, the creative way that Disney build its character and story also shows advantage in competing rewards. For example, the movie that discuss prejudice by many contrasting character Zootopia win the 89th academy award on the best animated film [6]. However, the "magic" of Disney does not work every time, there are critics mention the negative values that illustrate in Disney movie. One of them is the stereotype of the female body image in Disney princess. Although these stereotypes have been weaken after years, but some message still remains. [20] Although Disney do create princess from different culture background and show the beauty of girls being masculine, but the variation on female's character's shape and size is not enough.

\section{CONCLUSION}

The paper discusses different aspect that influence how Disney shape the film character. From history, culture to social consensus, all these factors influenced how these characters are illustrated. Even though it does not always satisfied audience, but most of the time consider these factors when shaping character contribute to a successful movie. The limitation of this paper included the limitation of example used in the paper. Most of the movie list in the paper are produced before 2015, although there are relatively new ones like Zootopia, the lack of current production makes the paper have limited discussion on the newest mindset and trend in Disney's production. Another limitation is that most movie discuss in the paper are animated film, although they are movies like Star Wars mentioned when discussing the historical background, but other Disney character like Marvel's superhero is not mentioned in the paper, which makes the discussion on the role Marvel's superhero in shaping individual heroism and how change of historical background influence the character of superhero being absent from the discussion.

\section{REFERENCES}

[1] Chaney, Jen. (2012, June 22). Pixar's 'Brave': Is its girl power message arriving too late? [Web log comment]. Retrieved from http://www.washingtonpost.com/blogs/celebritolog $\mathrm{y} /$ post/pixars-brave-is-its-girlpower-message-arriving-too-late/2012/06/21/gJQA icA0uV_blog.html

[2] Do Rozario, R.-A. C. (2004). The Princess and the Magic Kingdom: Beyond Nostalgia, the Function of the Disney Princess. Women's Studies in Communication, 27(1), 3459. doi:10.1080/07491409.2004.10162465

[3] Eric Herhuth (2014) Cooking like a Rat: Sensation and Politics in Disney-Pixar's Ratatouille, Quarterly Review of Film and Video, 31:5, 469-485

[4] Expression of Art and Beauty after Business Analyses "Zootopia" as an example to see Disney's value expression change in a century $[\mathrm{J}]$. Journal of 
Lanzhou University of Arts and Science (Social Science Edition), 2019,35 (03) : 119-123.

[5] England, Dawn E., Descartes, Lara, \& Collier-Meek, Melissa A. (2011). Gender role portrayal and the Disney princesses. Sex Roles, 64(1), 555-567. doi: 10.1007/s11199-011-9930-7

[6]https://www.oscars.org/oscars/ceremonies/2017

[7]https://www.boxofficemojo.com/title/tt1217209/?ref _-bo_se_r_1

[8]https://www.boxofficemojo.com/title/tt2294629/?ref _-bo_se_r_1

[9]Jiao Sue, Zhao Yanghua. Analysis of brand building and social culture value of "Star Wars" series of film [J] .Journal of Henan University of Technology (Social Science Edition), 2020, 21 (02): 37-43.

[10]Jin Li. American Female Rights, Female Literature - Women's Right Criticism [J]. American Research, 2009 (01).

[11]Law, Michelle. (2014). Sisters doin'it for themselves: Frozen and the evolution of the Disney heroine. Screen Education, 1(74), 16-25. Retrieved from

http://search.informit.com.au/documentSummary;d $\mathrm{n}=436282205645360$;res=IEL HSS

[12]Liu Yanfang. Idealistic artistic illusion - Cultural Analysis of "Zootopia" [J]. Art Appreciation, 2020 (16): 153-155.

[13]Li Zeyin. Study on the Evolution of Movie Women 's Image from the Perspective of Feminism - A Case Study of Disney Princess Series [J]. Audiovisual, 2021 (03): 97-99.

[14]Ma Hua. The "change" and "unchanged" in Chinese style cartoon - the inspiration from Mulan and Kungfu Panda Journal of Beijing Film Academy" 2009 No. 3

$\mathrm{Mu} \mathrm{Yu}$ : The Northern Dynasty war behind Mulan Literature and History, No 5, 2019

[15]O'Rourke, Jill. (2013, December 2). Why frozen's twist ending sends an awesome message to girls. [Web log comment]. Retrieved from http://www.crushable.com/2013/12/02/entertainme $\mathrm{nt} /$ frozen-ending-disney- princess-feminist/

[16]Rome, Jennifer M. (2013). Disney princess "2.0": A feminist critique of Disney' $s$ newest generation of princesses (Unpublished doctoral dissertation). University of Nebraska, Omaha.

[17]Saladino, Caitlin J. (2014). Long may she reign: A rhetorical analysis of gender expectations in
Disney's Tangled and Disney/Pixar's Brave (Unpublished doctoral dissertation). University of Nevada, Las Vegas.

[18]Tavin, Kevin M. and David Anderson. "Teaching (Popular) Visual Culture: Deconstructing Disney in the Elementary Art Classroom." Art Education 56.3 (2003): 21-35. Print.

[19]Whelan, Bridget. (2012). Third Wave Princess: Reconstructing and Redefining the Traditional Princess Narrative (Doctoral dissertation). Retrieved from ProQuest. (3548589).

[20]Zhang Bo. Analysis of Female Image in Disney Movie [J]. Movie Literature, 2016 (04): 49-51.

[21] Zhang Yi-mei, Zhang Zhe , Disney's Value Expresions and Centennial Changes:A Case Study of Zotopia [J]. Journal of Lanzhou University of Arts and Science (Social Sciences) ,2019,35(03):119-123. 